\title{
UPAYA GURU MENANAMKAN KEMANDIRIAN ANAK DALAM PEMBELAJARAN DI SENTRA SENI
}

\author{
Vini Melinda $^{1}$; Suwardi ${ }^{1}$ \\ ${ }^{1}$ Program Studi Pendidikan Guru Pendidikan Anak Usia Dini, Fakultas Psikologi dan Pendidikan, \\ Universitas Al Azhar Indonesia, Jalan Sisingamangaraja Kebayoran baru, Jakarta Selatan 12110 \\ Penulis untuk Korespondensi/E-mail: suwardi@uai.ac.id
}

\begin{abstract}
Abstrak - Kemandirian adalah sikap dan perilaku yang tidak mudah bergantung pada orang lain dalam menyelesaikan tugas-tugasnya sendiri. Kemandirian sangat penting dikembangkan pada anak usia dini agar menjadi individu yang mampu melakukan semua kegiatan dengan kemampuan dirinya sendiri tanpa campur tangan dari orang lain, inisiatif dalam menyelesaikan masalah, penuh ketekunan, dan memperoleh kepuasan dari usahanya sendiri. Salah satu sekolah yang menanamkan kemandirian yaitu KB-TK Islam Al Azhar 2 Pasar Minggu melalui pembelajaran di Sentra Seni. Penelitian ini bertujuan untuk menjelaskan upaya guru dalam menanamkan kemandirian anak usia $4-5$ tahun melalui kegiatan pembelajaran di Sentra Seni KB-TK Islam Al Azhar 2 Pasar Minggu. Metode penelitian yang digunakan berupa penelitian kualitatif deskriptif. Teknik pengumpulan data yang digunakan adalah observasi, wawancara, dan dokumentasi. Sumber data pada penelitian ini terdiri dari kepala sekolah, guru, dan anak-anak Kelompok A1 di Sentra Seni KB-TK Islam Al Azhar 2 Pasar Minggu. Hasil dari penelitian ini diketahui bahwa upaya yang dilakukan oleh guru dalam menanamkan kemandirian anak di Sentra Seni dilakukan dengan cara pemberian contoh (role model), pembiasaan, dan motivasi. Ketiga upaya ini dilakukan di setiap pijakan, yaitu Pijakan Sebelum Bermain, Pijakan Selama Bermain, dan Pijakan Sesudah Bermain.
\end{abstract}

Kata kunci: Kemandirian, upaya guru, pembelajaran, Sentra Seni.

Abstract - Independence is an attitude and behavior that is not easily dependent on others to complete one's own tasks. It is very important that independence is developed in early childhood so that they become individuals who are able to carry out all activities with their own abilities without interference from others, take initiative in solving problems, are full of diligence, and get satisfaction from their own efforts. One of the schools that instills independence is the Islamic Kindergarten Al Azhar 2 Pasar Minggu through learning at the Art Center. This study aims to explain the efforts of teachers in instilling the independence of children aged 4 - 5 years through learning activities at the Al Azhar 2 Islamic Kindergarten Arts Center Pasar Minggu. The research method used is descriptive qualitative research. Data collection techniques used were observation, interviews, and documentation. Sources of data in this study consisted of the principal, teachers, and children of Group Al at the Al Azhar 2 Islamic Kindergarten Arts Center Pasar Minggu. The results of this study show that the efforts made by the teacher in instilling the independence of children in the Art Center are carried out by giving examples (role models), habituation, and motivation. These three efforts are carried out on each step, namely the Footing Before Playing, the Footing During Playing, and the Footing After Playing.

Keywords: Independence, teacher effort, learning, Art Center. 


\section{PENDAHULUAN}

$\mathrm{K}$ emandirian adalah sikap dan perilaku yang tidak mudah bergantung pada orang lain dalam menyelesaikan tugastugasnya sendiri. Kemandirian sangat penting dikembangkan pada anak usia dini agar menjadi individu yang mampu melakukan semua kegiatan dengan kemampuan dirinya sendiri tanpa campur tangan dari orang lain, inisiatif dalam menyelesaikan masalah, penuh ketekunan, dan memperoleh kepuasan dari usahanya sendiri. Kemandirian dapat berkembang lewat latihan secara terus-menerus secara teratur sehingga menjadi kebiasaan pada diri anak. Oleh karena itu orangtua dan orang dewasa di sekitar harus memberikan bimbingan dan arahan kepada anak untuk mempersiapkan dirinya mengarungi kehidupan di masa mendatang.

\section{Kemandirian, Ciri, dan Faktor Kemandirian}

Kemandirian anak merupakan kemampuan anak untuk melakukan kegiatan dan tugas sehari-hari sendiri atau dengan sedikit bimbingan, sesuai dengan tahap perkembangan dan kemampuan anak (Majid, 2012). Menurut Steinberg (dalam Desmita, 2011) menyatakan bahwa kata mandiri memiliki arti kebebasan secara umum yang menunjuk pada kemampuan individu untuk melakukan sendiri aktivitas hidup tanpa bergantung dengan orang lain. Disisi lain menurut Erikson (dalam Desmita, 2011) kemandirian adalah usaha melepaskan diri dari orangtua dengan maksud untuk menemukan dirinya melalui proses mencari identitas ego, yang ditandai dengan kemampuan menentukan nasib sendiri, kreatif dan inisiatif, mengatur tingkah laku, bertanggung jawab, mampu menahan diri, membuat keputusan sendiri, serta mampu mengatasi masalah tanpa ada pengaruh dari orang lain.

Ketiga pendapat di atas dapat disatukan pengertiannya bahwa kemandirian adalah sikap atau kemampuan seorang anak untuk melakukan aktivitas hidup secara mandiri tanpa bergantung atau dengan sedikit bimbingan dari orang lain sesuai tahap perkembangannya, kreatif dan inisiatif, bertanggung jawab, serta dapat membuat keputusan sendiri.

Ciri-ciri kemandirian menurut Wiyani, (2013) menyatakan bahwa ciri-ciri kemandirian anak usia dini, adalah sebagai berikut: 1). Memiliki kepercayaan diri sendiri; 2). Memiliki motivasi intrinsik yang tinggi; 3). Mampu dan berani menentukan pilihannya sendiri; 4). Kreatif dan inovatif; 5). Bertanggungjawab menerima konsekuensi yang menyertai pilihannya; 6). Mampu menyesuaikan diri dengan lingkungannya; dan 7). Tidak bergantung dengan orang lain.

Tidak berbeda jauh dengan pendapat Fauziah (2018) tentang ciri-ciri kemandirian anak usia dini, yaitu: 1). Seorang anak yang memiliki rasa tanggung jawab dan kepercayaan diri; 2). Mampu dan mudah menyesuaikan diri dengan lingkungan; 3). Memiliki rasa ingin tahu yang tinggi dan selalu ingin mencoba sesuatu; 4). Tidak bergantung lagi dengan orang dewasa; 5). Selalu berusaha untuk melakukan sendiri selagi anak mampu; 6). Memiliki motivasi untuk memilih maupun melakukan sesuatu yang anak inginkan. Kemudian Yamin (2013) juga menjelaskan ciri-ciri anak yang mandiri untuk ukuran anak usia dini, diantaranya adalah sebagai berikut: 1). Dapat melakukan segala aktivitasnya sendiri meskipun tetap dengan pengawasan orang dewasa; 2). Dapat membuat keputusan dan pilihan sesuai dengan pandangan. Pandangan itu sendiri diperolehnya dari melihat perilaku atau perbuatan orangorang di sekitarnya; 3). Dapat bersosialisasi dengan orang lain tanpa perlu ditemani orangtua; dan 4). Dapat mengontrol emosinya, bahkan dapat berempati terhadap orang lain.

Berdasarkan tiga pendapat di atas yaitu pendapat dari Wiyani, Fauziah, dan Yamin, maka terkait penelitian ini ciri-ciri kemandirian yang akan digunakan adalah dengan menggabungkan pendapat mereka bertiga yang memiliki beberapa kesamaan. Tetapi, hanya 5 yang akan diambil dari ciri-ciri kemandirian tersebut sesuai dengan tahap perkembangan anak usia dini, yaitu: 1). Dapat melakukan aktivitasnya secara mandiri meskipun tetap dengan pengawasan orang dewasa; 2). Mampu dan berani menentukan pilihannya sendiri; 3). Mampu menyesuaikan diri dengan lingkungannya; 4). Memiliki rasa ingin tahu yang tinggi dan selalu ingin mencoba sesuatu.; dan 5). Selalu berusaha untuk melakukan sendiri selagi anak mampu dan tidak bergantung dengan orang dewasa. 
Wiyani (2013) mengemukakan bahwa faktorfaktor yang mendorong timbulnya kemandirian pada anak dibagi menjadi dua, yaitu:

1. Faktor Internal, terdiri dari kondisi fisiologis dan kondisi psikologis, yaitu:

a. Kondisi Fisiologis: Kondisi fisiologis merupakan kondisi yang berpengaruh antara lain keadaan tubuh, kesehatan jasmani, dan jenis kelamin.

b. Kondisi Psikologis: Meskipun kecerdasan atau kemampuan berfikir seorang anak dapat diubah atau dikembangkan melalui lingkungan, sebagian ahli berpendapat bahwa faktor bawaan juga berpengaruh terhadap keberhasilan mengembangkan kecerdasan seorang anak.

2. Faktor Eksternal, yaitu faktor yang meliputi:Lingkungan; Rasa cinta dan kasih sayang; Pola asuh orangtua dalam keluarga; dan Pengalaman dalam kehidupan.

Tidak jauh berbeda dengan yang disampaikan oleh Putra (2013) tentang faktor-faktor yang mempengaruhi kemandirian anak usia dini, yaitu: Faktor Internal, meliputi: Emosi. Dan Intelektual; dan faktor Eksternal, yang datang atau ada dari luar diri anak itu sendiri, meliputi: lingkungan; Karakteristik sosial; Stimulus; Pola asuh; Cinta dan kasih sayang; Kualitas interaksi anak dan orangtua; dan Pendidikan orangtua.

Faktor-faktor yang mempengaruhi kemandirian sangat menentukan tercapainya kemandirian seseorang. Begitu pula dengan kemandirian anak yang dapat dipengaruhi oleh faktor pendukung dari dalam diri anak itu sendiri ataupun faktor yang berasal dari luar.

\section{Upaya Menanamkan Kemandirian}

Upaya adalah kegiatan dengan menggerakan badan, tenaga, dan pikiran untuk mencapai suatu tujuan tertentu. Anjarwani (2018) berpendapat bahwa, upaya adalah bagian dari peranan yang harus dilakukan oleh seseorang untuk mencapai tujuan tertentu. Selain itu, upaya juga merupakan sebuah usaha atau ikhtiar yang dilakukan oleh seseorang dalam mencapai sebuah pencapaian tertentu yang sudah ditargetkan, dengan harapan upaya yang sudah dilakukan akan memberikan dampak yang maksimal kepada yang dituju.
Guru merupakan komponen penting dalam mengupayakan kemampuan peserta didiknya yang berkualitas di sekolah dengan menjaga keharmonisan antara perkataan, ucapan, perintah, dan larangan yang telah dibuatnya. Hal ini diharapkan akan menjadi sebuah tauladan yang baik untuk ditiru oleh peserta didik di sekolah. Seperti yang disampaikan oleh Soetjipto (2007), bahwa guru sebagai pendidik profesional mempunyai citra yang baik di masyarakat apabila dapat menunjukkan kepada masyarakat bahwa ia layak menjadi panutan atau teladan masyarakat sekelilingnya.

Untuk menanamkan kemandirian pada anak usia dini dapat dilakukan dengan berbagai upaya yang dilakukan. Menurut Yamin (2013) ada beberapa hal yang dapat menjadi perhatian dalam menanamkan kemandirian pada anak usia dini, yaitu:

1. Kepercayaan:

Sebuah kepercayaan yang diberikan oleh guru kepada anak akan menanamkan jiwa kemandirian, karena anak mulai mengembangkan kemandirian dengan kebebasan melakukan segala sesuatu dengan caranya sendiri. Seperti maju ke depan kelas untuk menceritakan pengalamannya, tidak bergantung kepada orang lain, sudah dapat ke kamar mandi sendiri, dan lain sebagainya.

2. Kebiasaan:

Pemberian kebiasaan yang baik harus diberikan kepada anak sesuai dengan usia dan tingkat perkembangannya, karena kemandirian akan muncul dengan sendirinya melalui pembiasaan yang dilakukan oleh guru. Dari pembiasaan yang dilakukan maka anak akan berfikir secara kreatif untuk melakukan hal yang positif.

3. Komunikasi:

Bahasa merupakan sarana yang efektif untuk menjalin komunikasi sosial. Komunikasi merupakan hal penting dalam melatih kemandirian anak. Karena dengan komunikasi yang jelas akan mempermudah anak untuk memahami dan mengerti bahasa tersebut.

4. Disiplin:

Kemandirian berkaitan erat dengan disiplin yang merupakan proses pengawasan serta bimbingan yang dilakukan orangtua dan guru secara konsisten. 
Dari empat hal yang menjadi perhatian dalam menanamkan kemandirian pada anak usia dini, tidak terlepas hanya dari upaya yang dilakukan oleh guru di sekolah, akan tetapi orang dewasa lainnya seperti orangtua, wali murid, pengasuh, dan lain-lain harus saling berkesinambungan agar tujuan utamanya dapat tercapai secara maksimal terhadap kemandirian anak.

\section{Perkembangan Kemandirian Anak}

Perkembangan kemandirian anak menjadi salah satu hal yang harus diperhatikan dan ditanamkan sejak anak berada di usia dini. Pencapaian perkembangan kemandirian anak dapat berkembang secara maksimal apabila mendapatkan stimulus yang tepat dari orang dewasa di sekitar lingkungan hidup seorang anak, seperti orangtua, wali murid, pengasuh, dan lain-lain.

Selain itu, hal ini juga dapat didukung dari pembelajaran anak selama di sekolah bersama guru dengan memberikan kegiatan-kegiatan yang dapat menanamkan kemandirian anak. Dari uraian di atas dan berdasarkan pendapat terkait dengan ciri-ciri kemandirian dari Wiyani (2013), Fauziah (2018), dan Yamin (2013), maka yang dimaksud dengan kemandirian dalam penelitian ini adalah kemampuan anak yang dapat ditandai dengan hal-hal sebagai berikut:

1. Dapat melakukan aktivitasnya secara mandiri meskipun tetap dengan pengawasan orang dewasa, meliputi:

a. Mengambil alat atau bahan seni dari tempat penyimpanan ke proses karya seni (K-1).

b. Membereskan kembali alat atau bahan seni yang sudah selesai digunakan (K2).

2. Mampu dan berani menentukan pilihannya sendiri, meliputi:

a. Menyusun berbagai bahan seni sesuai dengan apa yang diinginkan atau yang sudah dicontohkan dengan tambahan ide kreasinya sendiri (K-3).

b. Mengatakan apa yang sudah diselesaikan (K-4).

3. Mampu menyesuaikan diri dengan lingkungannya, meliputi:

a. Berbagi alat atau bahan seni dengan temannya (K-5).

b. Bekerjasama dengan temannya dalam berkegiatan di Sentra Seni (K-6).

4. Memiliki rasa ingin tahu yang tinggi dan selalu ingin mencoba sesuatu, meliputi:

a. Membuat atau menyusun sebuah karya seni menggunakan bahan-bahan seni sesuai dengan imajinasinya (K-7).

b. Memainkan permainan lain seperti lego saat sudah menyelesaikan pekerjaan karya seninya (K-8).

5. Selalu berusaha untuk melakukan sendiri selagi anak mampu dan tidak bergantung dengan orang dewasa, meliputi:

a. Mencari alat atau bahan seni untuk mendukung proses karya seni sesuai dengan yang dibutuhkan (K-9).

b. Mencari alat atau bahan seni lain untuk mendukung proses karya seninya apabila alat atau bahan seni yang diinginkan tidak ada (K-10).

\section{Pengertian Sentra Seni}

Sentra Seni adalah sentra yang dapat memberikan kesempatan kepada anak usia dini untuk mengembangkan kemampuan menggunakan dan berinteraksi dengan berbagai macam alat serta bahan seni, seperti: lem, gunting, crayon, clay, dan playdough. Sehingga dengan demikian menurut Hermansyah (2019), pengertian Sentra Seni adalah hal yang sangat penting bagi pengembangan keterampilan seni anak.

Hal ini sama dengan pengertian Sentra Seni menurut Dahlia (2013), dalam bukunya yang berjudul Implementasi dan Inovasi Kurikulum PAUD 2013 tentang Sentra Seni yang mengatakan bahwa, Sentra Seni merupakan kegiatan yang bertujuan untuk memberikan kesempatan kepada anak mengembangkan perkembangan keterampilan dan berkarya.

Selain itu, pengertian Sentra Seni menurut Asmawati (2010), merupakan sentra yang kegiatannya terdiri dari keterampilan tangan, seperti: melipat, menggunting, merekat, prakarya, melukis, dan pertukangan. Tidak hanya itu, anak juga diajarkan untuk lebih memperhatikan keindahan dan keserasian warna. Pada akhirnya anak akan membuat berbagai penemuan-penemuan yang berguna bagi mereka. 
Ketiga pendapat di atas dapat diartikan bahwa pengertian dari Sentra Seni merupakan hal yang sangat penting bagi perkembangan keterampilan seni anak. Karena Sentra Seni akan memberikan kesempatan kepada anak untuk mengembangkan kemampuan seninya seperti melipat, menggunting, merekat, melukis, dan prakarya dengan menggunakan berbagai macam alat serta bahan seni yang terdiri dari lem, gunting, crayon, clay, playdough, dan lainlain. Selain itu, di dalam Sentra Seni anak diajarkan untuk memperhatikan keindahan dan keserasian warna dalam berkarya.

\section{Kegiatan di Sentra Seni}

Pada Sentra Seni, tentu ada berbagai macam kegiatan yang dapat dilakukan oleh anak usia dini. Kegiatan-kegiatan tersebut menurut Latif (2016), terdiri dari menggambar dengan crayon atau spidol, melukis dengan kuas besar atau kecil dan alat-alat lainnya, menggunting, menempel pola atau gambar, kolase, mozaik, finger painting, dan prakarya dengan berbagai bahan jadi ataupun bekas. Sementara Asmawati (2010), menyatakan kegiatan di Sentra Seni terdiri dari keterampilan tangan seperti melipat, menggunting, merekat, prakarya, melukis, dan pertukangan. Kegiatan di Sentra Seni meliputi 3M (melipat, menggunting, merekat), bekerja dengan bahan sisa, merobek, mencap, membentuk dengan bermacam-macam alat, memercik, membuat cermin, bermain dengan cat minyak, stensil, dan menetes dengan lilin.

Berdasarkan pemahaman di atas maka di dalam Sentra Seni terdapat berbagai macam aktivitas yang dapat dilakukan oleh anak, seperti menggambar dan melukis menggunakan spidol, cat air, pensil warna, menggunting, menempel, serta membuat sebuah prakarya dengan melipat, merekat, membentuk, dan lain sebagainya.

Selain melakukan berbagai macam kegiatan, menyediakan peralatan dan perlengkapan yang dibutuhkan, tentu di dalam Sentra Seni memiliki aturan bermain sebelum anak melakukan kegiatan-kegiatan tersebut, dari Sibuea (2019), aturan bermain di dalam Sentra Seni, terdiri dari: 1). Memilih kegiatan yang disediakan; 2). Memulai dan mengakhiri kegiatan yang sudah dipilih; 3). Bekerja sesuai dengan kreasinya; 4). Melaporkan pekerjaan yang telah diselesaikan; 5). Berganti kegiatan seni yang lainnya, bila waktu masih memungkinkan; dan 6). Beres-beres dengan menyimpan kembali alat-alat yang telah digunakan ke tempatnya.

\section{METODE PENELITIAN}

Metode penelitian yang digunakan berupa penelitian kualitatif deskriptif. Subjek primer dalam penelitian ini terdiri dari 3 orang, yaitu: pertama Kepala Sekolah KB-TK Islam Al Azhar 2 Pasar Minggu, Guru Sentra Seni, dan Guru Kelas Kelompok A1. Kemudian untuk subjek sekunder dalam penelitian ini terdiri dari anak-anak Kelas A1 yang berada di dalam Sentra Seni berjumlah 10 anak yang dibagi dari 20 anak sebagai penunjang keberhasilan guru dalam upaya menanamkan kemandirian anak melalui Sentra Seni.Sumber data pada penelitian ini terdiri dari kepala sekolah, guru, dan anak-anak Kelompok A1 di Sentra Seni KB-TK Islam Al Azhar 2 Pasar Minggu.

Teknik pengumpulan data yang digunakan adalah observasi, wawancara, dan dokumentasi. Teknik analisis data dalam penelitian ini menggunakan analisis deskriptif. Karena data yang dikumpulkan berupa deskripsi atau kumpulan keterangan dari suatu fenomena yang menjadi masalah dalam penelitian ini, maka selanjutnya adalah mengolah data yang telah dikumpulkan dengan analisis data, mendeskripsikan data, dan menarik kesimpulan. Proses analisis data dimulai sebelum penulis memasuki lapangan, selama di lapangan, dan setelah selesai di lapangan

Adapun indikator kemandirian yang akan diamati adalah:

1. Dapat melakukan aktivitasnya secara mandiri meskipun tetap dengan pengawasan orang dewasa, meliputi:

a. Mengambil alat atau bahan seni dari tempat penyimpanan ke proses karya seni $(\mathrm{K}-1)$.

b. Membereskan kembali alat atau bahan seni yang sudah selesai digunakan (K2).

2. Mampu dan berani menentukan pilihannya sendiri, meliputi:

a. Menyusun berbagai bahan seni sesuai dengan apa yang diinginkan atau yang sudah dicontohkan dengan tambahan ide kreasinya sendiri (K-3). 
b. Mengatakan apa yang sudah diselesaikan (K-4).

3. Mampu menyesuaikan diri dengan lingkungannya, meliputi:

a. Berbagi alat atau bahan seni dengan temannya (K-5).

b. Bekerjasama dengan temannya dalam berkegiatan di Sentra Seni (K-6).

4. Memiliki rasa ingin tahu yang tinggi dan selalu ingin mencoba sesuatu, meliputi:

a. Membuat atau menyusun sebuah karya seni menggunakan bahan-bahan seni sesuai dengan imajinasinya (K-7).

b. Memainkan permainan lain seperti lego saat sudah menyelesaikan pekerjaan karya seninya (K-8).

5. Selalu berusaha untuk melakukan sendiri selagi anak mampu dan tidak bergantung dengan orang dewasa, meliputi:

a. Mencari alat atau bahan seni untuk mendukung proses karya seni sesuai dengan yang dibutuhkan (K-9).

b. Mencari alat atau bahan seni lain untuk mendukung proses karya seninya apabila alat atau bahan seni yang diinginkan tidak ada (K-10).

\section{HASIL DAN PEMBAHASAN}

Penanaman kemandirian mulai terlihat saat pijakan yang kedua sampai dengan pijakan yang keempat, yaitu Pijakan Sebelum Bermain sampai dengan Pijakan Setelah Bermain. Guru Sentra Seni menjelaskan bahwa densitas atau kegiatan bermain yang akan dilakukan oleh Anak Kelas A1, terdiri dari: 1.) Mengisi pola/kolase, 2.) Meremas kertas, 3.) Kreativitas membuat 2 permen yang berbeda, dan 4.) Membentuk kreasi dengan pasir sintetik. Sebelum melakukan kegiatan-kegiatan tersebut, Guru Sentra Seni memberikan contoh langkah-langkah dari setiap kegiatan dimulai dari bagaimana cara langkah pertama sampai langkah terakhir pembuatan karya seni di setiap kegiatan-kegiatan tersebut.

Kemudian Guru Sentra Seni menyampaikan peraturan bermain di Sentra Seni. Hal yang terlihat ketika Guru Sentra Seni sedang menyampaikan peraturan-peraturan tersebut Anak Kelas A1 menggerakan kedua tangannya sambil menyebutkan peraturan bermain di Sentra Seni. Peraturan bermain di Sentra Seni, terdiri dari: 1.) Fokus, 2.) Sayang teman, 3.) Berjalan, 4.) Bersuara pelan, 5.) Memilih kegiatan, dan 6.) Beres-beres.

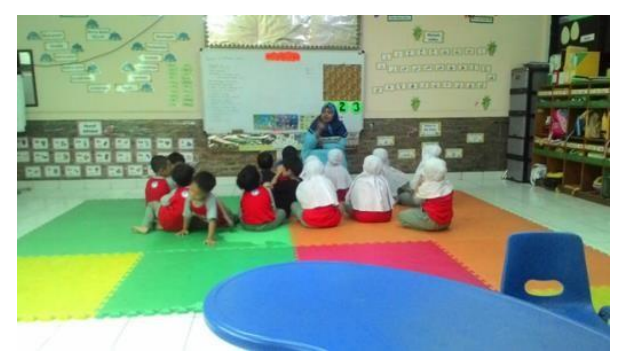

Gambar 1. Pijakan Sebelum Main

Adapun kemandirian anak yang terlihat pada pijakan yang kedua yaitu Pijakan Sebelum Bermain adalah terlihat Anak Q mengambil alat dan bahan seni dari tempat penyimpanan atau Sudut-Sudut ke proses karya seninya (K-1). Begitu pula dengan Anak RY yang mencari alat dan bahan seni untuk mendukung proses karya seni sesuai dengan yang dibutuhkan, seperti mengambil alat dan bahan untuk membuat kreasi 2 permen yang berbeda (K -9).

Pada pijakan yang ketiga yaitu Pijakan Selama Bermain, kemandirian anak selanjutnya terlihat pada saat Anak RY sedang menyusun kain flannel yang berukuran $25 \mathrm{~cm}$ sebanyak 2 buah dengan warna yang berbeda dan menggulungkannya menggunakan sedotan kecil untuk membantu proses penggulungan kain flannel tersebut. Setelah digulung, Anak RY mengambil selotipe untuk merekat hasil gulungan tersebut agar tidak terlepas sebelum nantinya hasil karya RY akan diberi lem tembak oleh Guru Sentra Seni (K-3). Kemudian saat membuat kretivitas permen yang satunya, terlihat Anak RY membantu Anak J untuk bekerjasama mengikat tali kasur di sisi kiri kain flannel saat membungkus kapas dengan kain tersebut. Sama hal nya dengan Anak RAI saat bekerjasama dengan AU untuk mengikat sisi kanan kain flannel (K-6).

Ketika Anak KI sudah selesai menggulung kain flannel pada saat membuat Permen Lollipop dan ingin merekatnya menggunakan selotipe terlihat selotipe yang dimaksud sedang dipakai oleh anak lain dan posisinya jauh dari jangkauan KI. Sehingga untuk mengganti selotipe tersebut Anak KI menggunakan lem 
sebagai pengganti perekat untuk merekatkan kain flannel agar tidak terbuka.

Selanjutnya, terlihat Anak Q bekerjasama dengan Anak A dan Anak AZ yang merupakan teman bermainnya $Q$ pada hari itu di Sentra Seni sedang menggunting- gunting kertas hijau sebagai rumput di karya kolase mereka (K-6). Setelah menyelesaikan pekerjaan ini, Anak Q dan teman bermainnya yaitu Anak A dan AZ memberitahu Guru Sentra Seni bahwa pekerjaan mereka mengisi pola/kolase sudah selesai (K-4).

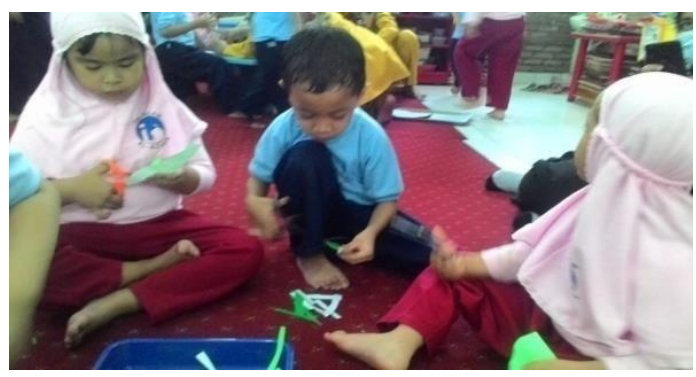

Gambar 2. Anak Q bekerjasama dengan Anak A dan Anak AZ saat menggunting-gunting kertas hijau

Pada saat kegiatan yang keempat yaitu membentuk kreasi dengan pasir sintetik, terlihat Anak $\mathrm{Z}$ bersama dengan teman bermainnya yaitu Anak QF dan K sedang membuat dan menyusun sebuah istana yang di sampingnya ada taman bunga menggunakan pasir sintetik (K-7). Disini Guru Sentra Seni bertanya kepada $\mathrm{Z}$ dan teman- temannya: "Wah cantik banget! Kalian sedang buat apa?", Anak Z menjawab: " $Z$ sedang buat istana bu, nanti $Q F$ dan $K$ tinggal di istana Z", Anak QF menjawab: "Kamarku besar, bu nanti bisa naro mobil di kamar". Tak lama kemudian, Anak K menjawab: "Tapi di istananya ada taman bunga bu.. K suka banget sama bunga-bunga, cantik". Selain itu, mereka juga berbagi pasir sintetik dengan teman kelompok lainnya yaitu kelompok Anak RAI ketika RAI, AU, dan KI kekurangan pasir sintetik saat bermain (K-5).

Pijakan yang keempat adalah Pijakan Sesudah Bermain, kemandirian anak yang terlihat adalah ketika Anak AT yang sudah menyelesaikan seluruh pekerjaannya memilih bermain balok dan membangun sebuah bangunan yaitu rumah
(K-8). Selanjutnya terlihat Anak A, Anak Q, Anak S, Anak RF membereskan kembali alat dan bahan seni yang sudah selesai digunakan ke tempatnya semula yaitu Sudut-Sudut, hal serupa juga dilakukan oleh Anak RAI, Anak KI, dan anak-anak lainnya (K-2).

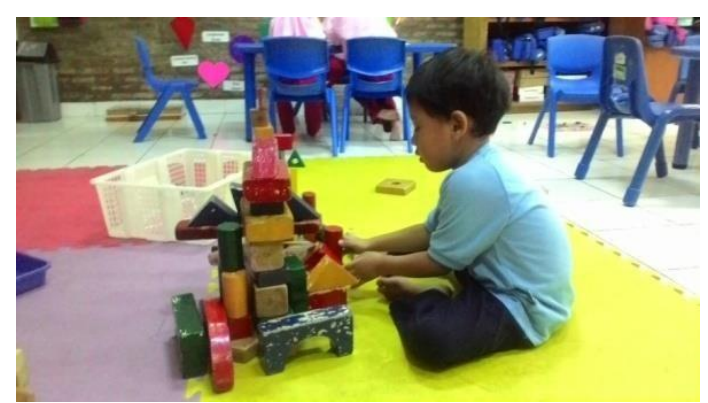

Gambar 3. Anak AT bermain balok saat sudah menyelesaikan pekerjaan karya seninya

Upaya yang dilakukan oleh Guru Sentra Seni untuk menanamkan kemandirian anak adalah dengan cara: 1.) Pemberian contoh (role model), 2.) Pembiasaan, dan 3.) Motivasi. Upaya berupa pemberian contoh (role model) adalah ketika Guru Sentra Seni sedang mencontohkan langkah-langkah bagaimana cara membuat suatu karya seni yang merupakan bagian dari kegiatan bermain anak di Sentra Seni. Guru Sentra Seni juga memberikan contoh bagaimana cara mengambil alat dan bahan seni di Sudut-Sudut yang sudah disediakan, mencontohkan bagaimana cara membereskan alat dan bahan seni yang sudah selesai dipakai, serta mencontohkan bagaimana cara membersihkan sisa-sisa bahan seni yang tidak terpakai dengan membuangnya ke tempat sampah.

Upaya guru berupa pembiasaan adalah ketika anak-anak sudah mulai terbiasa dan disiplin dalam mengikuti peraturan di Sentra Seni. Selain itu, anak-anak terlihat sudah hafal terhadap letak Sudut untuk mengambil dan mengembalikan alat serta bahan seni yang sudah dipakai ke tempatnya semula. Begitu pula pembiasaan yang dilakukan oleh anak untuk melakukan beres-beres dan membersihkan sisa-sisa bahan seni yang tidak terpakai dengan cara diambil atau dipungut, disapu menggunakan sapu kecil yang sudah disediakan, dilap menggunakan keset atau tissue, dan membuangnya ke tempat sampah. 
Upaya guru berupa motivasi adalah ketika ada anak yang belum mau mengembalikan dan merapihkan alat dan bahan seni ke tempatnya semula. Ketika hal ini tejadi, Guru Sentra Seni memberikan motivasi seperti yang terlihat dari hasil wawancara dengan Guru Sentra Seni pada hari Senin, 24 Agustus 2020 yang mengatakan bahwa: Metode lain yang digunakan guru sebagai upaya menanamkan kemandirian anak adalah dengan metode motivasi, seperti: "Masa waktu kita masuk ke Kelas Sentra Seni setelah Kelas A3 kesini, di meja bundar itu masih ada kertas, masih ada sampah, masih ada spidol. Kira-kira menurut anak-anak bagus ga kayak begitu?." Jawab Anak Kelas A1: "ga, ga rapih bu guru." Guru Sentra Seni menjawab: "Nah nanti kalo kalian belajar di Sentra Seni ga boleh seperti itu ya, jangan dicontoh. Kan kita datang ke Kelas Sentra Seni sudah bersih, nanti kita keluar dari Kelas Sentra Seni juga harus bersih ya, dengan cara apa? Ada yang tau?" Jawab Anak Kelas A1: "Dirapihin bu..." Guru Sentra Seni: "Iya betul, dengan cara merapihkan kembali kelas kita, Kelas Sentra Seninya. Bisa ya teman-teman?" Jawab anak: "Bisa bu!".

Selain itu, ketika ada anak yang terlihat bingung dan tidak tahu bagaimana membuat atau menggambar di karya seninya maka Guru Sentra Seni memberikan motivasi berupa pertanyaan kepada anak tersebut, seperti: "Tadi informasinya membuat apa?", "Coba lihat punya temannya", "Coba minta diajarkan dengan temannya". Tapi ada anak yang pemalu, biasanya Guru Sentra Seni men-switch atau menukar dengan teman yang lain, agar si anak tersebut bisa lihat dan tanya ke temannya untuk diajarin.

Upaya motivasi juga dilakukan ketika terdapat anak yang sulit bersosialisasi atau tidak mau bermain bersama temannya, misalnya berbagi lem, mengalah dari warna kertas origami yang berbeda, menunggu giliran penggunaan lap basah, membantu temannya yang sedang kesulitan, dan motivasi untuk membersihkan sisa-sisa bahan seni yang tidak terpakai. Sebelum diberi motivasi tentu Guru Sentra Seni bertanya kepada anak, terutama anak yang tidak mau bermain bersama temannya. Misalnya Anak K kan yang memang tidak mau bermain dengan bergantian dengan temannya si SH, Guru Sentra Seni bertanya: "Kenapa kamu gamau bermain bersama dengan si SH?", Anak
K menjawab: "Karena aku gamau temanan sama si SH." Guru Sentra Seni: "Disini kita bermain sama-sama sayang, ingatkan peraturannya Sayang Teman?" Anak K: “Aku gamau!" Kalau dengan cara tersebut ternyata Anak K masih tetap tidak bereaksi, maka Guru Sentra Seni menukar si SH dengan teman yang lain agar baik Anak K dan tentunya SH dapat mengerjakan pekerjaannya dengan mandiri dan maksimal.

Berdasarkan hasil wawancara dan observasi selama proses pembelajaran di Sentra Seni, telihat adanya hambatan berupa permasalahan perilaku pada anak yang disebabkan oleh faktor internal atau faktor eksternal. Beberapa contoh terkait permasalahan tersebut yang ditemui adalah: ketika ada anak yang tidak mau mengambil alat dan bahan seni serta mengerjakan karya seninya dengan alasan capek, tidak mau mengembalikan, merapihkan, dan membersihkan alat serta sisa bahan seni karena mengambil bahan seninya terlalu banyak sehingga anak malas untuk membersihkan dan merapihkannya.

Selain itu terkadang ada anak yang masih belum mengerti bagaimana cara membuat atau menggambar karya seninya, sehingga pembelajaran serta penilaian untuk anak tersebut menjadi tertunda dan membutuhkan waktu yang lebih. Hambatan lainnya adalah masih ditemukan ada anak yang tidak mau bekerjasama dan berbagi saat bermain di kegiatan Sentra Seni. Namun, ada solusi yang diberikan oleh Guru Sentra Seni berupa komunikasi dengan cara berdiskusi bersama anak terkait dengan hambatan-hambatan tersebut.

Kemandirian penting dimiliki oleh anak, dari hasil penelitian selama proses pembelajaran Sentra Seni, adapun kemandirian yang sudah dimiliki berupa mengambil alat atau bahan seni dari tempat penyimpanan ke proses karya seni. Kemampuan anak saat mengambil alat atau bahan seni menunjukkan anak mengetahui apa yang dibutuhkan untuk menyelesaikan pekerjaannya, begitu pula ketika anak membereskan kembali alat atau bahan seni yang sudah selesai digunakan ke tempatnya semula anak dapat melakukan aktivitasnya sendiri baik sebelum dan sesuah bermain. Kemampuan anak mengambil alat dan bahan seni serta 
membereskannya kembali merupakan ciri-ciri kemandirian anak sebagaimana pendapat (Yamin, 2013) bahwa salah satu ciri-ciri kemandirian anak usia dini adalah dapat melakukan segala aktivitasnya sendiri meskipun dengan pengawasan orang dewasa.

Selain kemampuan kemandirian anak dalam mengambil alat atau bahan seni dari tempat penyimpanan, tentu terdapat hal yang harus anak lakukan saat alat atau bahan seni yang diinginkan tidak ada yaitu mencari alternatif lain untuk memenuhi kebutuhannya di Sentra Seni. Kemampuan kemandirian ini terlihat pada Anak KI yang menggunakan lem sebagai pengganti perekat untuk merekatkan kain flannel agar tidak terbuka ketika membuat kreativitas 2 permen yang berbeda. Kemampuan kemandirian anak mencari alternatif alat atau bahan seni ini merupakan salah satu ciri-ciri kemandirian anak sebagaimana pendapat (Fauziah, 2018) yang mengatakan bahwa anak yang mandiri selalu berusaha untuk melakukan sendiri selagi anak mampu dan tidak bergantung dengan orang dewasa.

Selanjutnya, kemandirian lain yang sudah dimiliki oleh anak Kelompok A yaitu Kelas A1 di KB-TK Islam Al Azhar 2 Pasar Minggu melalui Sentra Seni, berupa kemandirian menyusun berbagai bahan seni sesuai dengan apa yang diinginkan atau yang sudah dicontohkan dengan tambahan ide kreasinya sendiri, seperti pada saat Anak RY membuat kreativitas 2 permen yang berbeda menggunakan kain flannel. Kemudian ketika anak-anak sudah selesai mengerjakan pekerjaannya di Sentra Seni, mereka akan memberitahu Guru Sentra Seni bahwa pekerjaan mereka sudah selesai. Kemampuan anak menyusun berbagai bahan seni sesuai dengan apa yang diinginkan dan memberitahu Guru Sentra Seni ketika pekerjaannya telah selesai merupakan salah satu ciri-ciri kemandirian anak menurut (Wiyani, 2013) bahwa anak yang berkarakter mandiri memiliki kemampuan dan keberanian dalam menentukan pilihannya sendiri.

Kemudian kemandirian lain yang sudah dimiliki oleh Anak Kelas A1 saat berada di Sentra Seni adalah kemampuan kemandirian untuk berbagi alat atau bahan seni dan bekerjasama dengan temannya. Hal ini terlihat ketika Anak AU berbagi bahan seni yaitu sedotan putih saat teman bermainnya AZ kehabisan bahan seni tersebut. Anak Z, QF, dan $\mathrm{K}$ berbagi pasir sintetik dengan teman kelompok lainnya yaitu kelompok Anak RAI ketika mereka kekurangan pasir sintetik saat bermain. Kemampuan berbagi dan bekerjasama anak- anak tersebut merupakan ciri-ciri kemandirian sebagaimana pendapat (Wiyani, 2013) bahwa anak yang memiliki karakter mandiri, ia akan mampu menyesuaikan diri dengan lingkungannya. Selain itu, kemampuan anak dalam berbagi dan bekerjasama dengan temannya penting dimiliki oleh anak usia dini. Menurut (Himaiko, 2018), pentingnya kerjasama bagi anak dapat melatih kepekaan anak, melatih kemampuan anak untuk berkomunikasi, melatih anak menjalin hubungan, dan melatih anak untuk dapat menghargai orang lain.

Kemampuan kemandirian lainnya yang terlihat dari Anak Kelompok A1 pada saat berada di Sentra Seni adalah kemampuan kemandirian untuk menyusun sebuah karya seni menggunakan bahan-bahan seni sesuai dengan imajinasinya. Hal ini terlihat ketika Anak Z bersama dengan teman bermainnya yaitu Anak QF dan $\mathrm{K}$ sedang membuat dan menyusun sebuah istana yang di sampingnya ada taman bunga menggunakan pasir sintetik. Kemampuan kemandirian anak dalam menyusun sebuah karya seni terlihat juga ketika Anak AT membangun sebuah bangunan rumah dari balok. Kemampuan anak dalam membuat dan menyusun sebuah karya seni menggunakan bahan seni sesuai dengan imajinasinya merupakan ciri-ciri kemandirian anak usia dini sebagaimana pendapat (Fauziah, 2018) bahwa salah satu ciri-ciri kemandirian anak usia dini adalah memiliki rasa ingin tahu yang tinggi dan selalu ingin mencoba sesuatu.

Dari hasil penelitian di Sentra Seni, sudah terlihat upaya-upaya yang dilakukan oleh Guru Sentra Seni untuk menanamkan kemandirian anak melalui berbagai hal, di antaranya adalah: 1.) Pemberian contoh (role model), 2.) Pembiasaan, dan 3.) Motivasi.

Upaya pertama berupa pemberian contoh (role model) terkait dengan kemandirian anak usia dini adalah saat Guru Sentra Seni memberikan 
contoh bagaimana cara mengambil alat dan bahan seni di Sudut-Sudut yang sudah disediaan, mencontohkan bagaimana cara membereskan alat dan bahan seni yang sudah selesai dipakai, dan mencontohkan bagaimana cara membersihkan sisa-sisa bahan seni yang tidak terpakai dengan membuangnya ke tempat sampah, dengan demikian dalam hal ini Guru Sentra Seni sudah melakukan upaya menanamkan kemandirian anak di Sentra Seni melalui pemberian contoh (role model).

Upaya yang kedua dalam menanamkan kemandirian anak di Sentra Seni adalah pembiasaan. Pembiasaan dilakukan ketika anakanak sudah mulai terbiasa dalam mengikuti peraturan di Sentra Seni. Hal ini sesuai dengan pendapat (Yamin, 2013) bahwa anak harus diberikan pembiasaan sesuai dengan usia dan tingkat perkembangannya. Pada akhirnya pembiasaan uang dilakukan oleh guru menjadi sebuah kedisiplinan bagi anak. Sesuai denganpendapat (Yamin, 2013) bahwa kemandirian berkaitan erat dengan disiplin yang merupakan proses pengawasan serta bimbingan yang dilakukan guru secara konsisten.

Upaya pembiasaan yang dilakukan secara konsisten dan setiap hari memberikan dampak yang positif terhadap kemandirian anak. Hal ini terlihat ketika anak-anak sudah hafal terhadap letak sudut untuk mengambil dan mengembalikan alat serta bahan seni yang sudah dipakai ke tempatnya semula. Begitu pula pembiasaan yang dilakukan oleh anak untuk beres- beres dan membersihkan sisa-sisa bahan seni yang tidak terpakai dengan cara diambil atau dipungut, disapu menggunakan keset atau tissue, dan membuangnya ke tempat sampah dengan demikian guru sudah melakukan upaya menanamkan kemandirian anak di Sentra Seni melalui pembiasaan.

Upaya guru yang ketiga untuk menanamkan kemandirian anak di Sentra Seni berupa motivasi. Motivasi terlihat ketika guru mengingatkan kepada anak tentang apa yang boleh dan tidak boleh dilakukan. Selain itu guru juga memotivasi dengan mengingatkan anak untuk mengembalikan alat dan bahan seni setelah selesai digunakan ke tempatnya semula. Kemudian guru juga memotivasi anak untuk menjaga kebersihan dan melakukan peraturan bermain yang sudah disebutkan agar anak bisa melakukan kegiatan di Sentra Seni sesuai dengan peraturan bermain tersebut. Motivasi guru yang diberikan untuk anak berupa ucapan, nasihat, dorongan, dan kalimat pujian, dengan motivasi tentu terdapat fungsi dari motivasi itu sendiri. Menurut pendapat (Heriyanti, 2013) motivasi dapat berfungsi untuk merangsang atau menstimulus anak dalam kegiatan belajar agar dapat berlangsung dengan baik. Sehingga motivasi penting diberikan untuk anak usia dini agar dapat mempertahankan kemauannya untuk belajar.

Motivasi selanjutnya berupa motivasi pertanyaan interaksi antara Guru Sentra Seni dengan anak, hal ini terjadi pada anak yang sulit bersosialisasi atau tidak mau bermain dengan temannya. Peristiwa tersebut bisa terjadi saat anak belum mau berbagi lem, mengalah, menunggu giliran penggunaan lap basah, belum mau membantu temannya yang sedang kesulitan, dan belum mau membersihkan sisasisa bahan seninya yang tidak terpakai. Sehingga upaya guru memotivasi anak dengan memberikan pertanyaan interaksi maupun arahan sudah sesuai, namun menurut (Yamin, 2013) motivasi itu sendiri bisa dilakukan dengan memberikan kepercayaan kepada anak.

Pemberian motivasi sebagai upaya guru dalam menanamkan kemandirian anak usia dini dapat dilakukan dengan cara komunikasi. Hal ini sesuai dengan pendapat (Yamin, 2013) bahwa komunikasi merupakan hal penting dalam melatih kemandirian anak, karena dengan komunikasi yang jelas akan mempermudah anak untuk memahami dan mengerti bahasa tersebut. Maka pemberian motivasi dengan cara komunikasi yang baik dan jelas tujuan yang ingin disampaikan oleh Guru Sentra Seni akan diterima dengan baik oleh anak.

Hasil observasi dan wawancara penelitian selama proses pembelajaran di Sentra Seni, terlihat adanya hambatan yang menyebabkan penanaman kemandirian anak kurang optimal. Hal tersebut dikarenakan adanya hambatan berupa permasalahan dari diri anak. Permasalahan tersebut terlihat ketika ada anak yang tidak mau mengambil alat dan bahan seni serta mengerjakan karya seninya dengan alasan capek, malas untuk mengembalikan, merapihkan, dan membersihkan alat serta sisa bahan seni, dan tidak mau bekerjasama atau 
berbagi dengan teman saat bermain di kegiatan Sentra Seni.

Adapun solusi yang dapat diberikan oleh Guru Sentra Seni untuk mengatasi hambatanhambatan tersebut berupa komunikasi dengan cara berdiskusi bersama anak. Hal ini sesuai dengan pendapat (Yamin, 2013) bahwa komunikasi yang jelas akan mempermudah anak untuk memahami dan mengerti bahasa tersebut. Sehingga tujuan dari yang ingin disampaikan oleh Guru Sentra Seni terkait dengan hambatan-hambatan tersebut dapat diterima oleh anak.

\section{SIMPULAN DAN SARAN}

Penanaman kemandirian yang diberikan selama pembelajaran di Sentra Seni terjadi pada setiap pijakan. Setiap pijakan tersebut Guru Sentra Seni memberikan role model, pembiasaan, dan motivasi sehingga kemandirian itu tertanam selama anak berada di Sentra Seni mulai dari Pijakan Sebelum Bermain, Pijakan Selama Bermain, dan Pijakan Sesudah Bermain. Upaya yang dilakukan oleh guru dalam menanamkan kemandirian anak di Sentra Seni dilakukan dengan cara pemberian contoh (role model), pembiasaan, dan motivasi. Ketiga upaya ini dilakukan di setiap pijakan, yaitu: Pijakan Sebelum Bermain, Pijakan Selama Bermain, dan Pijakan Sesudah Bermain. Metode yang dipakai dalam menanamkan kemandirian anak selama pembelajaran di Sentra Seni berupa praktek langsung dengan pemberian contoh dan motivasi kepada anak. Media yang digunakan untuk menanamkan kemandirian anak adalah media atau alat bantu yang dipakai berkaitan dengan kegiatan di Sentra Seni seperti kertas, lem, gunting, dan lain-lain.

Adapun saran yang dapat diberikan bagi guru: pertama, agar guru dapat melakukan pemberian contoh (role model), pembiasaan, dan motivasi di setiap pijakan yaitu: Pijakan Sebelum Bermain, Pijakan Selama Bermain, dan Pijakan Sesudah Bermain; kedua, seharusnya kegiatan yang diberikan di Sentra Seni dapat memberikan kebebasan anak untuk membuat hasil karya seni sesuai dengan keinginannya, sehingga perlu disediakan bahan-bahan seni yang lebih bervariasi agar anak bisa melakukan kebebasan tersebut.

\section{DAFTAR PUSTAKA}

Anjarwani, T. (2018). Upaya guru pendidikan agama islam dalam mengembangkan multiple intellegences siswa kelas VII Di SMP Swasta Karya Bunda Kec. Percut Sei Tuan. Medan: Universitas Islam Negeri Sumatera Utara.

Asmawati, L. (2010). Pengelolaan kegiatan pengembangan anak usia dini. Jakarta: Universitas Terbuka.

Dahlia, S. (2013). Implementasi dan inovasi kurikulum PAUD 2013 program pembelajaran bebasis multiple intelligences. Bandung: PT. Remaja Rosda Karya.

Desmita. (2011). Psikologi perkembangan peserta didik. Bandung: PT. Remaja Rosda Karya.

Fauziah, K. M. (2018). Perbedaan kemandirian anak ditinjau dari subyek pengasuhan orangtua dan kakek-nenek pada anak usia 5-6 tahun. Jurnal Penelitian dan Pengembangan Pendidikan Anak Usia Dini FKIP UNTIRTA, Volume 5, Nomor 1, Mei 2018, 75.

Heriyanti. (2013). Pemberian motivasi belajar pada anak usia 4-5 tahun di taman kanakkanak Mujahidin II Pontianak Timur. PG PAUD FKIP UNTAN, 2.

Hermansyah. (2019). Pembelajaran melalui sentra seni dalam mengembangkan kreativitas anak usia dini. Nur El-Islam, Volume 6, Nomor 1, April 2019, 9.

Himaiko. (2018). Pentingnya kerjasama bagi anak usia dini.

Latif, R. Z. (2016). Orientasi baru pendidikan anak usia dini teori dan aplikasi. Jakarta: Prenada Media.

Majid, D. A. (2012). Pendidikan karakter perspektif islam. Bandung: PT. Remaja Rosda Karya.

Putra, K.D. (2013). Perkembangan kemandirian anak usia dini (usia 4 - 6 tahun) di taman kanak-kanak Assalam Surabaya. Character: Jurnal penelitian Psikologi. Volume 01 Nomor 03.

Sibuea, W. (2019). Implementasi model pembelajaran sentra seni anak usia 4 - 5 tahun di taman kanak-kanak Islam Terpadu 
Jurnal AUDHI, Vol. 2, No. 2, Januari 2020

Nurul Ilmi tahun ajaran 2018/2019.

Medan: Universitas Islam Negeri

Sumatera Utara.

Soetjipto. (2007). Profesi keguruan. Jakarta: Rineka Cipta.

Wiyani, N. A. (2013). Bina karakter anak usia dini. Jogjakarta: Ar-Ruzz Media.

Yamin, J. S. (2013). Panduan PAUD pendidikan anak usia dini. Ciputat: Gaung Persada Press Group. 